\title{
ADAPTÁCIÓRA VÁLLALKOZNI
}

\author{
- AVAGY VÁLLALKOZÓI SZEREPEK MEGJELENÉSE \\ A KÖRNYEZET ÉS
}

AZ ALKALMAZKODÁS VISZONYÁBAN

A szerzố cikkében arra a kérdésre keresi a választ, hogy a kis- és középvállalkozások vezetôinek sajátos környezethez füzốdố viszonyát alapul véve milyen vállalkozói szerepek azonosíthatóak a környezeti változásokra való reagálás során. A kutatás központi kérdése, hogy a vállalkozó miként tekint magára az adaptációra a turbulensen változó környezeti viszonyok között, és magának milyen szerepet szán az alkalmazkodási folyamat során. A cikk bemutatja a vállalkozó személyiségének alapvetố vonásait, külön kitérve a vállalkozó vezetố személyére, majd ezt követôen az adaptáció legjellemzóbb formáit és tulajdonságait helyezi középpontba. A tanulmány 14 hazai kis- és középvállalkozás vezetójével készített interjú feldolgozásával, valamint Hortoványi és Szabó (2006a) adaptációs stratégiai típusai alapján három kategóriát azonosít a környezetfelfogás és reagálás kontextusában. ${ }^{1}$

Kulcsszavak: vállalkozói szerepek, stratégia, adaptáció, környezeti alkalmazkodás, változás

Maga a vállalkozó személye megragadható az újítás és alkotás kontextusában, Gartner (1989) szerint a vállalkozói lét nem más, mint szervezetek létrehozása, és ez az a tulajdonság, amely elkülöníti a vállalkozó személyét a nem vállalkozó személyétól. Schumpeter (1980) megközelítése alapján a vállalkozó nem más, mint az a személy, aki folyamatosan újít, új kombinációkat hoz létre. Hasonló megközelítést képvisel az az elmélet, mely szerint a sikeres vállalkozó olyan személy, aki olyan üzletet indított el, amely még nem létezett azelőtt (Homaday Bunker, 1970, in: Gartner, 1989). Ezen elméleti megközelítések mind azt hivatottak kifejezni, hogy a vállalkozó léte garancia az újító törekvésekre, az innovációra, a kreatív megoldásokra. Schumpeter (1980) felfogásában a vállalkozó megbontja a piac állandóságát, és új értéket hoz létre azáltal, hogy innovál, legyen az új üzleti modell, új termék vagy új erôforrás-kombinációk alkalmazása, így végez „kreatív rombolást”.

$\mathrm{Az}$ innováció, innovativitás kiemelt szerepet kapott a vállalkozói lét elemzésében, továbbá a vállalkozói hajlandóság kibővült olyan további adottságokkal, mint a proaktivitás, a kockázattudatosság vagy a di- namikus környezeti tényezókhöz való alkalmazkodás (Stevenson - Grumpert, 1985; Wickam, 2006), illetve az elóbb említettek mellett az autonómia vagy az agresszív versengés (Lumpkin - Dess, 1996). Hortoványi (2010) az innovativitást, a proaktivitást és a kockázatkezelést tekintette a vállalkozói hajlandóság fóbb dimenzióinak, illetve az autonómiát, valamint az agreszszív versengés és a növekedés orientációját is fontos dimenziónak tartja.

A proaktív magatartást a környezeti változásokra adott, jövớbeni igényeknek elébe menő válasszal, az anticipált trendekre alapozó magatartással és a versenytársakat megelőző újítások bevezetésével azonosították (Faragó, 2008). A proaktivitás előrelátó szemléletet foglal magában, amelyet innovatív tevékenységek kísérnek, így az ilyen formában létszükséglet a vállalkozás fejlődéséhez. Bár közeli kapcsolatban áll az agresszív versenyzéssel, nem tévesztendő össze vele, mivel a proaktivitás a piaci lehetôségek megragadását, a környezet megváltoztatására való hajlandóságot jelenti, amellyel megteremti a keresletet (Lumpkin - Dess, 1996). 
A proaktív magatartás megnyilvánul a piaci trendek felismerésében és olyan cselekvésben, mely a trendek megváltoztatására és befolyásolására irányul. A proaktív vezető́k pedig olyan személyek, akik kezdeményezốk, szembemennek a konvenciókkal és maguk alakítják a trendeket (Hortoványi, 2009; Szabó, 2008). Ilyen és ehhez hasonló tulajdonságok fedezhetôek fel Hortoványi (2010) vállalkozó vezetôjében, aki folyamatosan keresi az új lehetôségeket, miközben a szúkös vagy hiányos eróforrások problémájával is meg kell küzdenie. A vállalkozó vezetố másként tekint a vállalat erőforrásaira, mint az adminisztratív vezetô, akinek rendelkezésére állnak a szükséges erooforrások, és azok leghatékonyabb felhasználására törekszik. Az erőforrások hiányából fakadó lehetôség keresése, továbbá a vállalkozó vezetô olyan alapvetô képességei, mint például a lehetőségek proaktív felismerése és az erőforrások megszerzésének képessége viszik elöre a szervezetet. A vállalkozó vezetés célja, hogy megteremtse és állandósítsa a szervezet innovációs képességét, mely egyben azt is jelenti, hogy a szervezet képessé válik a változásokra való gyors reagálásra (Hortoványi, 2009: p. 59.).

\section{A stratégia és a környezet kapcsolatának vizsgálata}

A környezet dinamizmusából kiindulva a szervezet úgy biztosítja a stratégia illeszkedését, hogy egyszerre képes rugalmasan viselkedni és változni (Jennings, 2004). A változás képessége azért szükséges, mert a szervezetek múködési környezete folyamatosan és egyre gyorsuló ütemben módosul, alakul át, új piaci szereplók, piacok és fogyasztói igények megjelenésével. Ezekre a kihívásokra azonnali és gyors válaszreakciót kell adnia a vállalatoknak, annak érdekében, hogy versenyképességüket megórizzék (D’Aveni, 1995; Miles - Snow, 1978; Drucker, 1988). A környezet közvetlenül hat a szervezetre, a szervezeti teljesítményre és a vezetésre, bármilyen környezetben múködjön is a szervezet, annak a hatásait nem hagyhatja figyelmen kívül (Dobák, 2002: p. 185.).

Az első környezet és stratégia viszonyát vizsgáló kutatások, mint például Burns - Stalker (1961) vagy Lawrence - Lorsch (1969) szerint a szervezeti struktúrát egyértelmúen meghatározzák a környezeti tényezók, míg a késốbbiek álláspontja szerint a szervezet képes stratégiájával passzív vagy aktív módon befolyásolni a környezetét (Child, 1972; Dobák, 2002: p. 41.). A szervezeti struktúrának a stratégiához való illesztését először Chandler (1962) fogalmazta meg, mely a gyakorlatban azt jelentette, hogy kapcsolat van a növekedési stratégia és a vezetési struktúra között. Peters (1984) odáig jutott a kérdés vizsgálatában, hogy a szervezeti stratégia követi a struktúrát: a szervezetek olyan képességeket fejlesztenek ki, melyek hozzájárulnak ahhoz, hogy a környezethez való alkalmazkodás a szervezet belsố értékeiból (hagyományok, magatartási normák) induljon ki.

\section{Adaptációs stratégiák}

Napjaink szervezeteinek heterogén, komplex, dinamikus és gyorsan változó környezettel kell szembenézniük (D'Aveni, 1995). A környezet dinamizmusa és a választott stratégia kapcsolatának kérdésével a szervezeti adaptáció foglalkozik (Jennings, 2004), azonban a környezet változásaira csak a dinamikus szervezetek képesek megfelelően reagálni. A szervezet adaptációs képessége arra utal, hogy az milyen gyorsan és milyen hatékonyan képes illeszkedni a külső környezethez (Dobák, 2002: p. 179.).

Miles - Snow (1978) végzett a szervezetek adaptációjával kapcsolatos kutatásokat, melyek eredményeként az adaptáció négy típusát azonosították: a védekező, a kutató, az elemzó és a reagáló stratégiát. A védekezó stratégiát folytató vállalatok a stabilitás megórzésére törekednek, míg a kutatók dinamikusan reagálnak a környezeti változásokra, alapvetố képességük abban rejlik, hogy keresik és kihasználják a lehetôségeket a piacon. Az elemzó típus a védekezó és a kutató stratégiák egy sajátos ötvözete, a kutatók döntéseit követve egyszerre törekszik a piaci stabilitás megórzésére és egy dinamikus stratégia kialakítására. A reagáló stratégia abban nyilvánul meg, hogy a vállalat szinte kizárólag csak reagál a környezeti változásokra, és nem tud megfelelő válasszal szolgálni.

A környezeti kihívásokra a vállalatok a következôképpen reagálhatnak Hortoványi és Szabó (2006a) hazai kutatása alapján:

- elzárkózás: a vállalat nem követi a környezeti változásokat, ezeket késve ismeri fel, tudatosan nem reagál rájuk,

- lemaradás: a vállalat törekszik a fontosabb környezeti változások felismerésére, azonban ezekre a kihívásokra gyakran nem megfelelő válaszokat ad,

- kései követés (reaktív adaptáció): a vállalat gyakran felismeri a fontosabb környezeti változásokat és jellemzóen reaktív, a környezeti kihívásokra utólagosan reagáló stratégiát követ,

- gyors követés (preaktív adaptáció): a vállalat rendszerint képes előre jelezni a fontosabb környezeti változásokat, azoknak elébe menó, a változásokra időben felkészülő magatartást követ, 
- trendek meghatározása (proaktív befolyásolás): a vállalat képes előre jelezni a fontosabb környezeti változásokat, azokra idôben felkészül és megfelelő válaszokkal alkalmazkodik, sôt maga is törekszik a környezeti feltételek tudatos befolyásolására (Hortoványi - Szabó 2006a, in: Balaton et al., 2007).

A vállalati gyakorlatban leginkább jellemző, hogy az adott szervezet a követés valamilyen formáját választja a kockázatok csökkentése érdekében, tehát az adaptáció tudatos választás eredménye (Szabó, 2008), továbbá egy-egy adaptációs stratégia alkalmazása a vállalatok számára nem jelent kizárólagosságot.

$\mathrm{Az}$ innovációs hajlam és a stratégia szempontjából Hortoványi és Szabó (2006a) kutatása alapján az entrepreneur (vállalkozói, aktív), az offenzív (támadó, aktív), illetve a defenzív (védő, passzív) stratégiák határozhatók meg. A vállalkozások tulajdonságait (innovativitás, kockázatkezelési hajlandóság) figyelembe véve ez a tipizálás a leginkább megfelelő a vállalkozások adaptációs stratégiájának vizsgálatára:

- az entrepreneur (vállalkozó, aktív stratégia) vállalatok esetében az innováció rendszeres és kiemelt fontosságú, a dolgozók számára egyértelmúen megfogalmazott a szerepe,

- az offenzív (támadó, aktív) stratégia: az innováció fontos tevékenység, ugyanakkor az újítások elfogadása és a kockázatvállalási hajlandóság kisebb, mint az entrepreneur vállalatok esetében,

- a defenzív (védő, hárító, passzív) stratégia: sem az innovativitás, sem a kockázatvállalás nem kap kiemelkedő szerepet a vállalati értékrendben.

Az entrepreneur vállalatok jövőorientáltak, rendíthetetlenül haladnak a kitüzött cél felé úgy, hogy közben kiemelt fontosságúnak tekintik az innovációt, az új ötletek megvalósítását, mindezt a kis lépések politikáját követve. A második csoportnál is jelen van az újításra törekvés, de egy olyan értékrend mentén, mely jellemzően konzervatív. A defenzív vállalatok pedig jellemzően csak utólagosan reagálnak egy-egy újításra (Hortoványi - Szabó, 2006a; Szabó, 2008).

1. ábra

Adaptációs stratégiák összevetése

\begin{tabular}{|c|c|c|}
\hline Entrepreneur & Trendek meghatározása & Kutató \\
\hline \multirow{2}{*}{ Offenzív } & Gyors követés & \multirow{2}{*}{ Elemzö } \\
\hline & Kései követés & \\
\hline \multirow[b]{2}{*}{ Defenzív } & Lemaradás & Reagáló \\
\hline & Elzárkózás & Védő \\
\hline
\end{tabular}

Forrás: Balaton et al. (2007)
Az adaptáció e kétféle tipizálása párhuzamba állítható egymással (1. ábra) (Szabó, 2008), mivel az entrepreneur vállalatokra a proaktivitás, az offenzív vállalatokra a pre- és reaktív viselkedés a jellemzó, míg a defenzív vállalatok az elzárkózás vagy a lemaradás stratégiáját folytathatják.

Az adaptációs stratégiák egy további tipizálási lehetőségét azonosította Hortoványi és Szabó (2006b) az EU-csatlakozás idején végzett magyarországi kutatása, melyben vezetó, alkalmazkodó, differenciáló, technológia vezérelte, beszállító és fókuszáló típusokat különböztetett meg. Szabó (2011) empirikus kutatás alapján alátámasztotta, hogy több integrált adaptációs stratégia és stratégiai archetípus is lehet hatékony és eredményes a környezet függvényében, illetve valamennyi adaptációs stratégia életképes a különbözó iparági ciklusokban.

A kis- és közepes vállalkozás előnye, hogy rugalmasságuk révén könnyebben alkalmazkodnak a megváltozott környezethez és gyorsabban ismernek fel egy-egy változást, mivel nem problémaként, hanem lehetôségként közelítik meg azt (Murray, 1984). Ez az innovatív mentalitás új versenyzôi magatartást és környezeti változások iránti magasabb fokú érzékenységet eredményez, melyek segítségével eredményesebb stratégiai válasz adható a turbulens környezeti változásokra (Dilts - Prough, 1987).

A vállalkozások turbulensen változó környezete olyan stratégiai hozzáállást követel meg a vállalatvezetôk részérôl, mely az alapvető változásra fókuszál, szemben a rendszer fenntartására irányuló vagy a kis lépések politikáját reagáló adaptációval (Murray, 1984). E tekintetben csakis a proaktív magatartás lehet célravezetô és eredményes a vállalkozások stratégiai adaptációja során, mely a vállalkozó vezető egyik sajátja (Hortoványi, 2010).

A szerző jelen tanulmányában abból az alapvetésból indul ki, hogy az entrepreneur vállalatokra a proaktivitás, az offenzív vállalatokra a pre- és reaktív viselkedés a jellemzô, míg a defenzív vállalatok az elzárkózás vagy a lemaradás stratégiáját folytathatják, Szabó (2008) alapján. A szerzó célja e stratégiák jellemzői alapján annak azonosítása, hogy a KKV-szektor esetében milyen környezethez való alkalmazkodásról és vállalkozói szerepekrôl beszélhetünk az adaptáció kapcsán.

\section{A kutatás módszertani háttere}

A kutatás során a szerző kvalitatív interjúkon alapuló kutatást folytatott. Miles és Huberman (1994: p. 6.) szerint a ,kvalitatív kutatás egy területtel vagy egy élethelyzettel való intenzív és/vagy egy hosszan tartó érintkezésen

\section{VEZETÉSTUDOMÁNY}


vezet végig. Ezek a helyzetek általában közönséges, normális szituációk, amelyek az egyének, csoportok, társadalmak és szervezetek mindennapi életét tükrözik viszsza. Ennek során a kutató szerepe, hogy egy holisztikus (rendszerszerú, átfogó, integrált) képet kapjon a kutatás alapján annak logikájáról, elrendeződésérool, explicit és implicit szabályairól."

A kvalitatív kutatási eljárás strukturálatlan, feltáró jellegư kutatási módszer, amely kis mintán alapul, és a probléma megértését szolgálja. A kvalitatív eljárásokat két csoportra oszthatjuk: így az eljárások lehetnek közvetlenek vagy közvetettek. A közvetlen megközelítés nyílt, az eljárás során a projekt céljait ismertetik a megkérdezettekkel, vagy az interjú jellege alapján ez egyértelmú számukra. Ezzel szemben a közvetett megközelítés során a moderátor elrejti a kutatás valódi célját a válaszadó előtt (Malhotra, 2001: p. 203.).

A közvetlen technikák legfontosabb fajtái a fókuszcsoportos interjúk és a mélyinterjúk. A fókuszcsoportos interjú strukturálatlan interjú, amelyben egy képzett moderátor beszélget a válaszadók egy kis csoportjával. A mélyinterjú strukturálatlan, közvetlen, személyes interjú, amelyben egy magasan képzett kérdezô beszélget egyetlen megkérdezettel, azzal a céllal, hogy feltárja motivációit, nézeteit, attitúdjeit és érzéseit egy adott kérdés vonatkozásában (Malhotra, 2001: p. 203-206.).

A mélyinterjúk jellemzője, hogy egy meghatározott probléma körüljárására alkalmas, előnye a fókuszcsoporttal szemben, hogy a válaszadót nem befolyásolja a csoport véleménye, azaz nincs szociális nyomás. A mélyinterjúk révén mélyebb problémafeltárás valósulhat meg, kényes témák felvetésével. A jelen kutatás egyéni mélyinterjúk lebonyolításával történt meg, egy kvalitatív esettanulmányos kutatás volt. Az esettanulmány célja, hogy választ adjon a hogyan és miért kérdésekre, továbbá lehetőséget adjon egy-egy elmélet kidolgozására (Yin, 1994).

Módszertanát tekintve a tanulmány „A kutatási és fejlesztési tevékenység lehetőségei és korlátai a KKV-szektorban" kutatás múhelytanulmány-sorozat 1. számú kötetének módszertani hátterére támaszkodik (Ferincz, 2011), egy kvalitatív mélyinterjúkon alapuló esettanulmányos kutatás, mely 14 kis- és középvállalkozás vezetőjével készített interjú feldolgozásán és elemzésén alapul.

\section{Elemzés: a vállalkozók szerepe az adaptációs folyamatban}

Jelen tanulmány elemzésének és következtetéseinek alapját egy 14 mélyinterjúból álló, több eseten alapuló esettanulmányos kutatás szolgáltatta. Az interjúalanyok mindegyike egy-egy magyarországi kis- és közepes vállalkozás vezetôje volt. A tanulmány célja, hogy az elméletben megalapozottaknak megfelelően a környezetre való reagálásban egy-egy jellemzô vállalkozói magatartást, hozzáállást fedezzen fel. Az elemzőmunka az alábbi nagyobb témák mentén zajlott:

- vállalkozások és környezetük,

- proaktivitás jegyei,

- reagáló magatartás jegyei,

- lemaradó magatartás jegyei.

\section{Vállalkozások és környezetük}

A vizsgált vállalkozások mindegyike folyamatosan változó környezetben múködik: „Ha az ember már tudja, hogy mire számíthat, akkor nem éri váratlanul, hogy most miért maradnak el a megrendelések, tehát ez. egy folyamatosan változó környezet." (12. alany) Eltekintve tehát attól, hogy milyen iparágról vagy piaci szegmensról beszélünk, fontos megjegyezni, hogy a piac változásainak követése, a versenytársak figyelése és a piaci változások előrejelzése mind olyan feladatok, melyeknek a mindennapi múködés részévé kell válniuk ahhoz, hogy egy-egy vállalkozás sikeres legyen a saját területén. Megjelennek a környezet különbözó szegmensei, tágabb értelemben: „nem ragadhatjuk ki magunkat az EU jogi környezetéból” (7. alany), szúkebb értelemben: „ez az iparág is, mint makrogazdasági szerepló, függ a környezettól” (2. alany).

A környezet befolyásoló szerepe bár triviálisnak tünhet, mégsem hagyható figyelmen kívül. Felvetődik a kérdés, hogyha ,a teljes környezet úgymond 180 fokot fordult körülöttünk" (14. alany), azaz egy óriási mértékú változás következett be az iparágakban, azt miképpen lehetett volna előre jelezni? Fontos megjegyezni, hogy az interjúk egy olyan válságterhes időszak után születtek, mely válság hatásait a nagyvállalatok sem tudták előre jelezni. Mindazonáltal - a válságtól eltekintve - a szerző amellett érvel, hogy az előrejelzés szükséges és fontos egy proaktív adaptációs stratégiához. Az a szervezet, amely nem képes vagy nem tud a piaci változásokra egyszerre hatékony és gyors válasszal szolgálni, lemarad a versenytársai mögött az iparági versenyben, lemaradó vagy követő pozícióba kerül.

A válságot követő stabilizálódás időszaka hasonlóan nehéz feladatot ró a szervezetekre, amikor a hangsúly az újrakezdésre helyezôdik át, megnó annak a jelentősége, hogy mennyire képesek változni és megújulni. A versenytársakat megelőző́en bevezetett újítás, innováció új lendületet adhat a vállalkozás számára, ,hogy nemcsak akkor kell innoválni, amikor egy versenytárs erósödik” (1. alany), követóból ugyanolyan lendülettel válhat trendmeghatározóvá és piacvezetôvé. Ha a vállalkozás 
vezetőjében nincs meg a versenytársaknál elóbb reagálás igénye, ha „csak a piachoz alkalmazkodóan kell újat csinálni" (9. alany), akkor a szervezet úgy akar fejlődni, hogy közben követô stratégiát folytat, és csupán lemásolja az új technológiákat, eredményeket.

A környezetre való reagálás tekintetében a szerző a vállalkozásokat három nagy csoportba sorolja, melyek a proaktív, a követó és a lemaradó vállalkozó csoportok. Mindegyik csoportban meghatározó a vállalkozó személye és személyisége abban a tekintetben, hogy miként tekint a környezetre való reagálásra.

\section{A proaktivitás jegyei}

A proaktív, változásoknak elébe menô felfogás jó példája: „,figyelni a többi versenytárs múködését, az is lényegében a munkához tartozik" (12. alany), folyamatosan nyomon követni az eseményeket, vagy követni a piacot és a piaci trendek alakulását úgy, hogy „,részt veszünk nemzetközi kiállításokon, versenyeken - akár kiállitóként is -, megpróbáljuk a nemzetközi környezetet is figyelemmel kísérni, a trendeket követni" (9. alany). Elébe lehet menni a versenytársaknak egy minden részletre kiterjedô piac- és versenytárselemzéssel. Az indulás is körültekintő piac- és versenytárselemzést követel meg, nem elég csupán a szerencsére, illetve a megérzésre hagyatkozni az elinduláskor: „Mielótt ez az egész elindult, egy komoly piackutatási munka elózte meg" (1. alany), illetve „a Magyarországon fellelhetó szaküzleteket mi azért inkognitóban tesztnek vetettük alá" (2. alany). $\mathrm{Az}$ üzleti ötletek bizonyos időközönként történó felülvizsgálata nemcsak javasolt, de szükséges is, „hogy vannak zsákutcák, de ezeket folyamatosan felül kell vizsgálni" (9. alany), mert a gyorsan változó körülmények között elveszítheti realitását és életképességét. A vállalkozói hajlandóság következtetni enged arra, hogy a vállalkozó miképpen értékeli a környezeti változásra adott stratégiai választ. Proaktív szemléletre utal, ha a vállalkozás érzékeny a piaci újításokra: „ébernek kell lenni” vagy „ugrani az új lehetóségek láttán” (6. alany). Az a vállalat vagy vállalkozás, amelyik figyelmen kívül hagyja a környezet változásait, lemarad az iparági versenyben, tehát a környezet változásaira való reakció elengedhetetlen a versenyelôny megórzéséhez.

„Fontos az, hogy nemcsak akkor kell innoválni, amikor egy versenytárs erốsödik, erốs vagy megerósödött, hanem fontos az, hogy ettól függetlenül folyamatosan legyen egyfajta innovácio" (1. alany), ezzel a felfogással a vállalkozó proaktívan elébe megy a változásoknak, néhány lépéssel a versenytársak előtt járva a megújulásban. A legfontosabb az újítókedv akkor is, amikor relatíve biztos a vállalkozás helyzete, hiszen a folyamatos újítással képes piaci pozícióját még inkább megerősíteni: „,nagyon dinamikus piac, folyamatosan figyelni kell, ébernek kell lenni és ugrani az új lehetốségek láttán” (6. alany), mivel,,gyakorlatilag folyamatosan szükség lenne rá, minden újszerú megoldásra vevó lehet a piac" (10. alany). A leginkább ez foglalhatja össze a gondolkodás lényegét: „De míg más nem meri, én igen. Ha látok benne rációt, és ebben láttam, és ezért mertem ebbe az egészbe belevágni" (1. alany), azaz cselekedni, megelózve a versenytársakat, és megelózve a piaci változást.

A fenti idézetek kiválóan alátámasztják azt az elózetes megállapítást, hogy a vállalkozás vezetójének proaktív és elóremutató szemlélete alapvetốen határozhatja meg az adaptációs stratégia irányát. A proaktivitás azonosítható jegyei: piacfigyelés, trendek nyomon követése, versenytársak elemzése, üzleti ötletek folyamatos felülvizsgálata, új lehetóségek azonositása és kihasználása.

\section{A követố magatartás jegyei}

A stabilitásra való törekvés jelenik meg az alábbi interjúalany felfogásában, de sok vállalkozás esetében egyre inkább általánosan elfogadottá válik: ,semmi probléma nincsen ezzel, hogyha van egy stabil üzletmeneted, de ahogy mondtam, sarkaiból képes kifordulni a környezet körülötted egyik napról a másikra, akkor az óhatatlanul is arra kényszeríti a felelós vállalkozásvezetôt, hogy minél stabilabb, minél kevésbé sebezhetó legyen a cég" (14. alany). Önmagában a stabilitásra való törekvés csak akkor zárja ki a proaktív stratégiát, ha a vállalkozás eközben nem tud, vagy nem akar a pozíciójából kimozdulni, és elébe menni a környezeti változásoknak.

Ha a vállalkozó csak ,fejben elébe megy” (2. alany), de a megvalósítás elmarad, az már csak passzív, legjobb esetben is követô reakciónak minôsül, és nem fog versenyelőnyt eredményezni. Ez annyiban több a lemaradásnál, hogy megvan a törekvés a kitörésre, de nem követik konkrét lépések. „Nem arról van szó, hogy a piachoz alkalmazkodóan kell újat csinálni" (9. alany) szintén egy pre-, illetve proaktív szemlélet megvalósulása, az első mindent visz felfogás érvényesülése, ahol az alkalmazkodás és követés nem lehet releváns opció a vállalkozás számára. „Sokan a versenytársaink közzül nem mernek úgy gondolkodni, hogy »merjünk nagyok lenni« (5. alany), mely azt jelenti, hogy a piacvezető pozíció elérésének célként való kitúzése, vagy akár proaktív gondolkodás révén kitörés az adott piaci pozícióból, hiányzik.

„A megújulás az már nem is cél, hanem követelmény" (4. alany), mivel elengedhetetlen újítani és folyamatosan megújulni. Hogyha ez a szemléletmód hiányzik, akkor kevésbé valószínú, hogy a vállalkozás eredményesen helytáll a piaci versenyben. 
Úgy is összefoglalhatnánk, hogy a vállalkozók több potenciált látnak a múlt vállalkozói környezetében, mint a jelen kaotikus viszonyaiban: „10-12 évvel ezelótt az ember megtette volna ezt szemrebbenés nélkül azért, mert olyan volt a vállalkozási környezet, ami, hogy is mondjam, sokkal pozitívabb környezetet jelentett" (13. alany), pedig lehetóség nem volt és nem lesz kevesebb, csak hosszabb erófeszítést és kitartást igényel azok felismerése. Meg kell említeni a különböző korlátokat, melyek fóleg anyagi természetükból adódóan gördítenek elmozdíthatatlan akadályokat az előremutató lépések elé: „Hát, önmagában a hajlandósággal nincs gond, csak ugye van az, hogy meddig éri meg. Persze sok mindent szeretnénk, de hát megint, ugye, mindig azért a pénz beleszól"

(11. alany), „Én ellensége vagyok a hitelnek, mert inkább odáig megyek el, ameddig a lehetóségeim keretet nyújtanak erre" (12. alany). Az a felfogás érvényesül, hogy addig nyújtózkodjunk, ameddig a takarónk ér, inkább kövessünk, de ne vállaljunk nagyobb terhet, mint amekkorára a vállalkozás képes.

A követố stratégia és a lemaradó közti különbség élesen nem válik el a vizsgált vállalkozásokban, leginkább úgy foglalható össze a követố szemlélet lényege, hogy a vállalkozók látásmódja nem elóremutató, a múltbeli változtatásoknak nagyobb jelentốséget tulajdonítanak, hiányzik a bátorság a változások végrehajtásához és a rendelkezésre álló eróforrások kreatív felhasználásához, továbbá a status quo fenntartására való törekvés jellemzi.

\section{A lemaradó magatartás jegyei}

A lemaradó magatartás az interjúk alapján egyrészt megfogható azzal, hogy a nem cselekvést az eróforrás-hiánnyal magyarázza: amikor ,gyakorlatilag nem tudom ezt megtenni, mert nincsenek meg az anyagi eszközeim” (2. alany), vagy időhiányra: „nincs energiám arra, hogy valami vadonatúj dologba vágjak, és két évig öntsem bele a pénzt és az energiát" (13. alany), de ezek a megállapítások egyértelmúen a vállalkozói felfogás hiányára utalnak.

Másrészt, amikor a piacot a vállalkozó gyakorlatilag állandónak és változatlannak tekinti, ahova „, a nagy újdonságok nem törnek be" (14. alany). Így amikor a piacot és az iparágat olyan stabilnak és állandónak gondolja, hogy megítélése szerint nem szükséges megújulni és proaktívan a versenytársak és a verseny elébe menni: „mi jövóre is ugyanazt fogjunk termelni, meg tíz év múlva is, ilyen szempontból nincs megújulás" (8. alany).
A lemaradók nem érzik a változtatás szükségességét, a piacot állandónak, statikusnak gondolják, így a „nem reagálás” útját választják, nemhogy megújulni, de változni is képtelenek.

\section{Következtetés: vállalkozói szerepek az adaptációban}

Az interjúk, valamint Hortoványi és Szabó (2006a) kutatási eredményei alapján felépített modell célja, hogy a környezeti reagálás felfogása alapján meghatározza a vállalkozó szerepét az adaptációs stratégia kialakításában.

2. ábra

Stratégiák és vállalkozói felfogások

\begin{tabular}{|l|l|l|}
\hline defenzív & offenzív & entrepreneur \\
\hline lemaradó & követố & proaktív \\
\hline hátramaradó & változatlanságra törekvő & elóremutató \\
\hline
\end{tabular}

Forrás: saját készítés

A 2. ábra tipizálása Hortoványi és Szabó (2006a) alapján abból indul ki, hogy az innováció és az adaptáció kapcsolatában három adaptációs stratégiát azonosítottak (entrepreneur, offenzív és defenzív stratégiák).

Az adaptációs stratégiákat a modell összeköti a - fent elemzett - környezetre adható lehetséges válaszokkal, mely lehet proaktív, követố és lemaradó. A modell alapja, hogy Szabó (2008) szerint az entrepreneur vállalatokra a proaktivitás, az offenzív vállalatokra a pre- és reaktív viselkedés a jellemzó, míg a defenzív vállalatok az elzárkózás vagy a lemaradás stratégiáját folytathatják. Mivel a proaktivitás egyszerre adaptációs stratégia, és tekinthető vállalkozó vezetői adottságnak, így egyaránt jellemzi a vállalkozó szemléletét is. Az adaptációs stratégiákból és a környezetre adott reagálásból következik egyfajta vállalkozói szerepfelfogás az adaptációs folyamatban, melyek:

- a hátramaradó,

- a változatlanságra törekvố és

- az elöremutató szerepek.

Aszerint, hogy a vállalkozó milyen szerepet játszik az adaptációs folyamatban, megkülönböztethetők a hátramaradó, a változatlanságra törekvő és az előremutató lépéseket tevő vállalkozói kategóriák. Definíció szerint proaktivitás jellemzi a vállalkozó vezetóket (Lumpkin - Dess, 1996; Hortoványi, 2009), azonban nem minden vállalkozás vezetôje tekinthetô vállalkozó típusú vezetőnek, ami megmutatkozik a különböző környezeti hatásokhoz való viszonyulásukban is.

Az elóremutató szerep az, amelyik leginkább megfelel Hortoványi (2010) vállalkozó vezetójének és a vállalkozó vezetố felé támasztott proaktivitási köve- 
telményeknek. Lépései kezdeményezók, ösztönzi az innovációt, a fejlesztést, célja egy olyan piaci pozíció elérése, mellyel a versenytársak elé kerülhet, és akár trendmeghatározó is lehet a piacon. A vállalkozó vezetố a környezethez való proaktív viszonyával igyekszik minél inkább elemezni, nyomon követni és megfigyelni a piaci változásokat, trendeket, és igyekszik ezekre a lehetố leggyorsabb választ adni. Ahogy az entrepreneur stratégia önmagában versenyelőnyt jelent (Hortoványi - Szabó, 2006a), úgy eredményezhet az előremutató szerep is versenyelőnyt, mivel egy olyan típusú reakcióra épül, amely a versenytársak elótti cselekvésen alapul.

Egyrészról a vállalkozó magára vállalja az újító, elôremutató törekvéseket, kezdeményezốkészsége megnyilvánul a folyamatos változási szükség felismerésében. Változik a piac, változik a környezet, mellyel együtt kell változni, hiszen az utólagos cselekvés vagy nem cselekvés nem válasz: az a szervezet, amely nem képes vagy nem tud a piaci változásokra egyszerre hatékony és gyors válasszal szolgálni, lemarad a versenytársai mögött az iparági versenyben, valamint megtorpan a növekedésben.

A változatlanságra törekvó szerep lényege összefoglalható a statusquo fenntartására való törekvésben, mely nem azért újít, hogy megelôzze a versenytársait, hanem hogy a biztonságos utat választva kövesse óket. A követés jellemzi a környezethez való viszonyát is, mivel a környezet változásaira csak lassan vagy megkésve reagál, a piaci helyzet és a statusquo megórzésére törekszik, nem vállal feleslegesen kockázatot egy nagyobb nyereség elérése érdekében. Piaci helyzete stabilnak mondható, de nem tekinthetô iparágában úttörônek vagy kezdeményezőnek. Így az a tipikusan vállalkozó vezetônek azonosított tulajdonság sem jellemzi, mely a lehetőségek folyamatos keresésében és megragadásában jelenik meg. A szerep jellegzetessége, hogy a környezet változó voltát elismeri, de a saját vállalkozása pozícióján már annál nehezebben változtat. A statusquot inkrementális újításokkal kívánja fenntartani úgy, hogy közben nem vállal jelentôs kockázatot: stabil piaci pozíciójából egy kockázatosabb lehetőség vagy újítás révén sem akar kimozdulni.

Míg az offenzív stratégia egyfajta aktív alkalmazkodás abban a tekintetben, hogy az innováció sze- repét nem hanyagolhatjuk el, addig a változatlanságra törekvő vállalkozói szerep egy passzív „,szemlélődô” szerepként értelmezhetô. Ha követi is az újításokat és a piaci trendeket, csak azért teszi, mert tisztában van a környezet változó voltával, de ô maga változni nem akar ilyen sebességben, az inkrementális újításokat helyezi elótérbe. A vállalkozó ugyan folytat valamilyen adaptációs stratégiát, mely a követés valamilyen formájában jelenik meg.

A hátramaradó szerep viszonylag egyértelmú, megfeleltethetô az előremutató szerep ellentétének. A vállalkozó nem reagál a piaci változásokra, amely stratégiai szempontból azt jelenti, hogy defenzív stratégiát folytat, környezethez való viszonyában pedig a lemaradás jellemzi. Stabilitásra való törekvése olyan erős, hogy megfeledkezik a változó környezetról, nem követi figyelemmel a vállalkozását érintő változásokat: az új piaci trendeket, versenytársakat, vagy azok újításait. Ha reagál is ezekre, akkor lassan, konkrét stratégiai megfontolás nélkül teszi.

Ez a reagálás már minden szempontból megkésett, ha az előző kategória passzívan szemlélődô volt, akkor ez a statikus nem reagáló kategóriája. A környezeti változásoktól elzárkózik, részben az izoláció jegyeit mutatja e kategória. Elhárítja a változások szükségességét, és így lemarad a piaci versenyben a versenytársai mögött, nem tud megújulni, így fejlődni sem. A piacot is változatlannak tekinti, a megújulást pedig fölöslegesnek és szükségtelennek. Nem jellemzi tehát a vállalkozó vezetốkre jellemzô innovativitás és jövőorientáltság vagy a lehetőségek keresése és megragadása, így a többi előremutató és változatlanságra törekvő versenytársa is le fogja hagyni.

3. ábra

\section{a reagálás tekintetében}

Hátramaradó

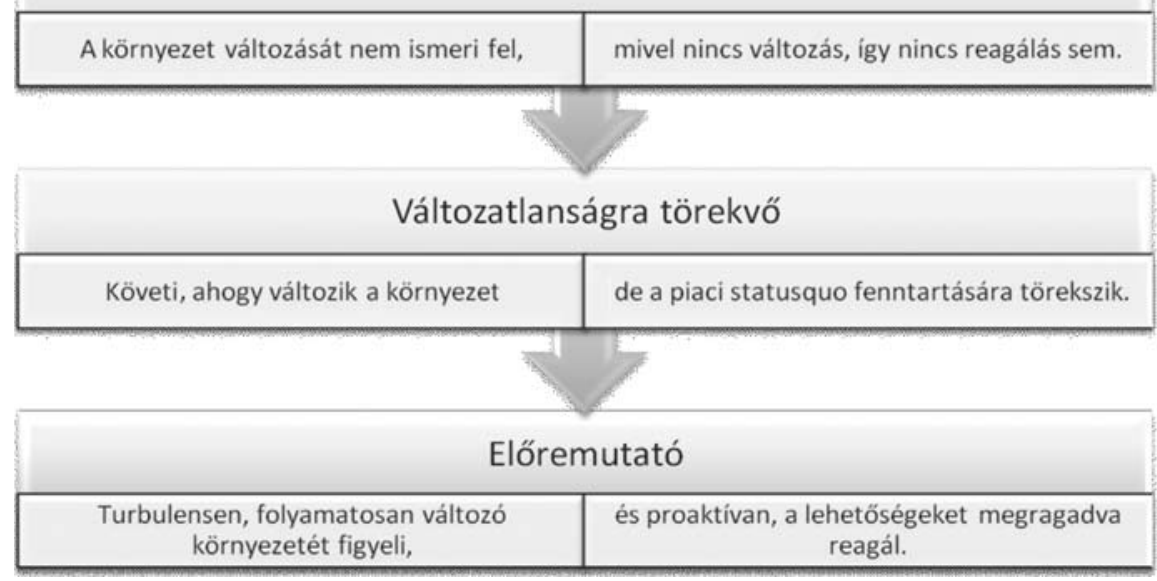

Forrás: saját készítés 
Az azonosított három szerepkategória jól mutatja, hogy a vállalkozók különbözóképpen reagálnak az óket érô változásokra, másképp tekintenek magára a környezetre, amely így eltéró szerepeket is azonosít a környezethez való alkalmazkodás során (3. ábra). Az elmélet szerint a vállalatok proaktív magatartása a vezetôi, illetve a vállalat vállalkozói hajlandóságán múlik és ennek következtében független a külsố környezeti feltételektôl (Stevenson - Jarillo, 1990). A kutatás alapján a szerepet az határozza meg, hogy a vállalkozó felismeri-e a környezet változásait és ezekre a változásokra miképpen reagál, tehát alapvetốn függ a környezettôl. A környezeti változásokban rejlő lehetôséget nem minden vállalkozás képes felismerni és a maga javára fordítani. A lehetőség felismeréséhez pedig vállalkozó vezetőkre (Hortoványi, 2009) van szükség, akik folyamatosan az újabb lehetőségeket keresik, ehhez pedig új erooforráskombinációkat használnak fel még akkor is, amikor az erőforrások csak szúkösen állnak rendelkezésre.

Jelen cikk jól illeszkedik az adaptációval és kettős képességgel kapcsolatos friss kutatási eredményekhez. A környezet pedig egyfajta moderátorszerepet tölt be a vállalkozói szemlélet és a teljesítmény viszonyában. Helfat és Winter (2011) a változások sebességét és szervezetre való hatásait vizsgálta: dinamikus képességek gyakran támogatnak kevésbé radikális változtatásokat rövid távon, és nem szükségszerúen turbulensen változó környezetben. Érdemes a dinamikus képességeket kamatoztatni hosszú távon és lassabb változás esetén is. Egy új termék létrehozása vagy egy új telephely létrehozása bár rutinos tevékenység lehet a vállalat számára, a piacon nagymértékú változást eredményezhet, így fontos mérni a változás mértékét, természetét és sebességét. Egy másik megközelítésben az innováció és a dinamikus képességek kapcsolatának vizsgálata (Parthasarathy et al., 2011) azt mutatja, hogy a dinamikus képességek termékinnovációt, míg az emberierőforrás-alapú dinamikus képesség folyamatinnovációt eredményeznek.

Összefoglalásként a vállalkozó vezetô olyan alapvetố képességei, mint például a lehetôségek proaktív felismerése, viszik előre a szervezetet, mely proaktivitás meglétét érdemes lehet nagyobb mintán, különböző iparágakban és környezeti feltételek mellett tovább vizsgálni. További kutatásokra ad lehetőséget a különböző környezeti változásokra adott válaszok megvizsgálása és összevetése a vállalkozó felfogásával annak érdekében, hogy tovább árnyalható legyen az adaptáció és a vállalkozói készségek közötti kapcsolat. Érdekes kérdést vet fel a vállalkozó szerepe különböző környezeti feltételek esetén, illetve az említett eltérő környezeti feltételek eredményezhetnek-e szerepkonfliktust a vállalkozó különböző szerepei esetében.

\section{Lábjegyzet}

${ }^{1}$ A cikk a TÁMOP-4.2.1.B-09/1/KMR-2010-0005 azonosítójú projektje, ,A tudásalapú gazdaság Magyarországon, az innovációs szemlélet erősödésének és a $\mathrm{K}+\mathrm{F}$ teljesítmények növelésének feltételei" címet viselő alprojektjének kutatási tevékenysége eredményeként készült.

\section{Felhasznált irodalom}

Balaton K. - Hortoványi L. - Incze E. - Laczkó M. - Szabó Zsolt R. - Tari E. (2007): Stratégiai és üzleti tervezés. Budapest: Aula Kiadó

Burns, T. - Stalker, G.M. (1961): The Management of Innovation. London: Tavistock

Chandler, A.D. (1962): Strategy and Structure. Cambridge, Mass.: MIT Press

Child, J. (1972): Organisational Structure, Environment and Performance: The Role of Strategic Choice. Sociology, Vol. 6, No. 1, p. 1-22.

D’Aveni, R.A. (1995): Coping With Hypercompetition: Utilizing The New 7S's Framework. Academy of Management Executive, Vol. 9, No. 3, p. 45-60.

Dilts, J.C. - Prough, G.E. (1987): Entrepreneurial Strategies for Managing the Changing Competitive Environment. Business Forum, Vol. 12, No. 4, p. 30-33.

Dobák M. (2002): Szervezeti formák és vezetés. Budapest: KJK-KERSZÖV Jogi és Üzleti Kiadó

Drucker, P.F. (1988): The Coming of the New Organization. Harvard Business Review, Vol. 66, No. 1, p. 45-53.

Faragó, K. (2008): Siker és kockázatvállalás a szervezetben. in: Márkus György (ed.): Kis- és középvállalatok, mint a gazdaságélénkítés tényezői. Budapest: Általános Vállalkozási Főiskola

Ferincz A. (2011): A kutatási és fejlesztési tevékenység lehetôségei és korlátai a KKV-szektorban - Kutatási módszertanésavizsgáltesetekbemutatása.Múhelytanulmány. Budapest: BCE Vezetés és Stratégia Tanszék

Gartner, B.W. (1989): "Who Is An Entrepreneur?" Is The Wrong Question. Entrepreneurship: Theory-Practice, Vol. 13, No. 4, p.47-68.

Helfat, C.E. - Winter, S.G. (2011):Untangling Dynamic and Operational Capabilities: Strategyfor the Neverchanging World. Strategic Management Journal, Vol. 32, No. 11, p. 1243-1250.

Hortoványi L. (2009): Vállalkozó vezetés Magyarországon múködő kis- és középvállalkozásokban. PhD-disszertáció. Budapest: Budapesti Corvinus Egyetem

Hortoványi L. (2010): Vállalkozó vezetés Magyarországon. Vezetéstudomány, Vol. 41, No. 4, p. 21-31.

Hortoványi L. - Szabó Zsolt R. (2006a): Pillanatfelvétel a magyarországi kis-és közepes vállalkozások vállalkozási hajlandóságáról. „Versenyben a világgal 2004-2006Gazdasági versenyképességünk vállalati nézópontból” címú kutatás. 27. múhelytanulmány. Budapest: BCE Versenyképesség Kutató Központ 
Hortoványi L. - Szabó Zsolt R. (2006b): Vállalati stratégiák az EU-csatlakozás idején Magyarországon. Vezetéstudomány, Vol. 37, No. 10, p. 10-23.

Jennings, P.L. (2004): Strategic Adaptation: A Uni Or Multi Dimensional Concept? Strategic Change, Vol. 13, No. 1, p. $1-10$.

Lawrence, P.R. - Lorsch, J.W. (1969): Organization and Environment. Homewood, Ill.: Irwin

Lumpkin, G.T. - Dess, G.G. (1996): Clarifying The Entreprenurial Orientation Construct And Linking It To Performance. Academy of Management Review, Vol. 21, No. 1, p. 135-172.

Malhotra, N.K. (2008): Marketingkutatás. Budapest: Akadémiai Kiadó

Miles, M.B. - Huberman, M.A. (1994): Qualitative data analysis. London: Sage

Miles, R. - Snow, C. (1978): Organizational Strategy, Sturcture and Process. New York: McGraw-Hill

Murray, J.A. (1984): A Concept Of Entreprenurial Strategy. Strategic Management Journal, Vol. 5, No. 1, p. 1-13.

Parthasarathy, R. - Huang, C. - Ariss, S. (2011): Impact of Dynamic Capability on Innovation, Value Creation and Industry Leadership. The IUP Journal of Knowledge Management, Vol. 9, No. 3, p. 59-73.
Peters, T.J. (1984): Strategy Follows Structure: Developing Distinctive Skills. California Management Review, Vol. 26, No. 3, p. 11-25.

Stevenson, H.H. - Jarillo, J.C. (1990): A paradigm of entrepreneurship: Entrepreneurial management. Strategic Management Journal, Vol. 11, No. 5,p. 17-27

Schumpeter, J.A. (1980): Theory of Economic Development. New York: Oxford Univ. Press

Stevenson, H.H. - Gumpert, D.E. (1985): The Heart Of Entrepreneurship. Harvard Business Review, Vol. 63, No. 2, p. 85-94.

Szabó Zsolt R. (2008): Adaptációs stratégiák a kialakuló bioetanol-iparágban. Vezetéstudomány, Vol. 39, No. 11, p. 54-63.

Szabó Zsolt R. (2011): Stratégiai adaptáció és kettős versenyképesség Magyarországon 1992 és 2010 között. in: Dobák M. - Bakacsi Gy. - Kiss Cs. (ed.): Stratégia és menedzsment. Budapest: Budapesti Corvinus Egyetem Vezetéstudományi Intézet

Wickham, A.P. (2006): Strategic entrepreneurship. London: Pearson Education

Yin, R.K. (1994): Case Study Research (2nd ed.). London: Sage 